УДК 159.9 .016

DOI https://doi.org/10.26661/2310-4368/2020-2-19

\title{
ТЕХНОЛОГІЇ ПСИХОПРОФІЛАКТИЧНОЇ РОБОТИ В КОНТЕКСТІ ОНТОГЕНЕЗУ ТА ДИЗОНТОГЕНЕЗУ ОСОБИСТІСНОГО СТАНОВЛЕННЯ ПІДЛІТКІВ
}

\author{
Литвиненко О. О. \\ кандидат психологічних наук, \\ доиент кафедри практичної психології \\ Київський університет імені Бориса Грінченка \\ вул. Бульварно-Кудрявська, 18/2, Київ, Украӥна \\ orcid.org/0000-0003-2152-7285 \\ o.lytvynenko@kubg.edu.ua
}

Ключові слова: підлітковий вік, психопрофілактика, тренінг, онтогенез, дизонтогенез, особистісне становлення.
У статті представлено результати розробки та апробації тренінгової програми психологічної профілактики, спрямованої на гармонізацію особистісного становлення підлітків. Специфіка програми полягає в іiі спрямованості на роботу із трьома основними сферами особистості: когнітивною, афективною та поведінковою, а також у методологічній орієнтації на загальні принципи та окремі методики когнітивно-поведінкової терапії. Мета статті полягає у представленні методологічної орієнтації та змістового наповнення програми, а також в аналізі результатів ефективності їі реалізації із трьома групами підлітків: тими, які мають порушення слуху та зору, а також тими, хто не має порушень у роботі аналізаторів. Як методи дослідження було використано анкетування та суб'єктивне шкалювання. У ході статистичного аналізу даних відбувалось порівняння двох виборок (до початку тренінгової роботи та після ії завершення) за допомогою t-критерію Стьюдента, аналізу середніх величин та стандартних відхилень. Отримані результати свідчать про високу ефективність тренінгової роботи 3 кожною 3 досліджуваних категорій підлітків, а також про можливість і доцільність ії використання як у форматі групової роботи (очних зустрічей), так і в дистанційному режимі 3 використанням спеціально розроблених онлайн завдань. При цьому найбільш ефективною виявилась робота 3 підлітками, що належать до умовнонормативної групи, а також тими, які мають порушення слуху. Це дозволило реалізувати спробу об'єднання учасників із двох зазначених категорій в єдину інклюзивну групу, результати діяльності якої підтверджують ефективність роботи в такому форматі. Висновки. Описана програма психологічної профілактики може бути використана для практичної роботи з підлітками, чиє особистісне становлення відбувається як у контексті онтогенезу, так і в контексті дизонтогенезу. Перспективи подальшої діяльності в цьому напрямі полягають у вдосконаленні дистанційної модифікації програми та в розробці специфічних алгоритмів іiі реалізації на базі наявних інтернет-майданчиків, призначених для такої роботи. 


\title{
THE TECHNOLOGIES OF PSYCHOLOGICAL PROPHYLACTICS IN THE CONTEXT OF ONTOGENESIS AND DYSONTOGENESIS OF ADOLESCENTS' PERSONAL FORMATION
}

\author{
Lytvynenko O. O. \\ Ph.D. in Psychology, \\ Associate Professor at the Department of Practical Psychology \\ Borys Grinchenko Kyiv University \\ Bulvarno-Kudriavska str., 18/2, Kyiv, Ukraine \\ orcid.org/0000-0003-2152-7285 \\ o.lytvynenko@kubg.edu.ua
}

Key words: adolescence, psychological prophylactics, training, ontogenesis, dysontogenesis, personal development.

\begin{abstract}
The article presents the results of training program creation and testing. This program of psychological prevention is aimed at harmonizing of the adolescents' personal forming. The specificity of the program lies in its focus on working with three main spheres of personality: cognitive, affective and behavioural, as well as in the methodological focus on general principles and separate methods of cognitive-behavioural therapy. The aim of the article is to present the methodological orientation and content of the program, as well as to analyse the results of its implementation within three groups of adolescents: those who have hearing and visual impairments, and those who do not have disorders of analysers. Questionnaires and subjective scaling were used as research methods. During the statistical analysis of the data, the two samples were compared (before and after the training work) using Student's t-test, analysis of mean indexes and standard deviations. The obtained results testify the high efficiency of training work with each of the adolescents' categories, as well as the possibility and feasibility of its use in the format of group work (face-to-face meetings) and in the distance format using specially designed online tasks. The most effective was the work with adolescents who belong to the conditional-normative group, as well as with those who have hearing impairments. This allowed making an attempt to combine participants from these two categories into a single inclusive group. The results of this group confirm the effectiveness of work in this format. Conclusions. The described program of psychological prevention can be used for practical work with adolescents whose personal development occurs both in the context of ontogenesis and in the context of dysontogenesis. Prospects for further activities in this direction are to improve the online modification of the program and to develop the specific algorithms for its implementation on the basis of existing Internet platforms designed for such work.
\end{abstract}

Постановка проблеми. Специфіку перебігу процесу становлення особистості підлітків як в онтогенезі, так і в дизонтогенезі можна охарактеризувати, аналізуючи три особистісні сфери: когнітивну, афективну та поведінкову. Різноспрямований взаємозв'язок між окремими компонентами цих сфер зумовлює цілісність формування вікових новоутворень та системність становлення основних рис і проявів особистості. Урахування результатів проведеного нами емпіричного дослідження [1] дозволило відповідно до кожної сфери виокремити складові частини, які характеризують гармонійне особистісне становлення підлітків. При цьому гармонійність процесу особистісного становлення ми вбачаємо у: 1) відповідності його віковим нормативам формування новоутворень; 2) суб'єктивному переживанні індивідом психоемоційного благополуччя; 3) готовності до наступного періоду вікового розвитку - юнацького віку.

Досягнення загальної гармонійності $є$ можливим за рахунок гармонійного функціонування кожної із трьох особистісних сфер. Тому нами було виокремлено і описано критерії гармонійного становлення та функціонування кожної 3 особистісних сфер і представлено параметри, відповідно до яких можна зробити висновок про їх патологізацію (рис. 1). 


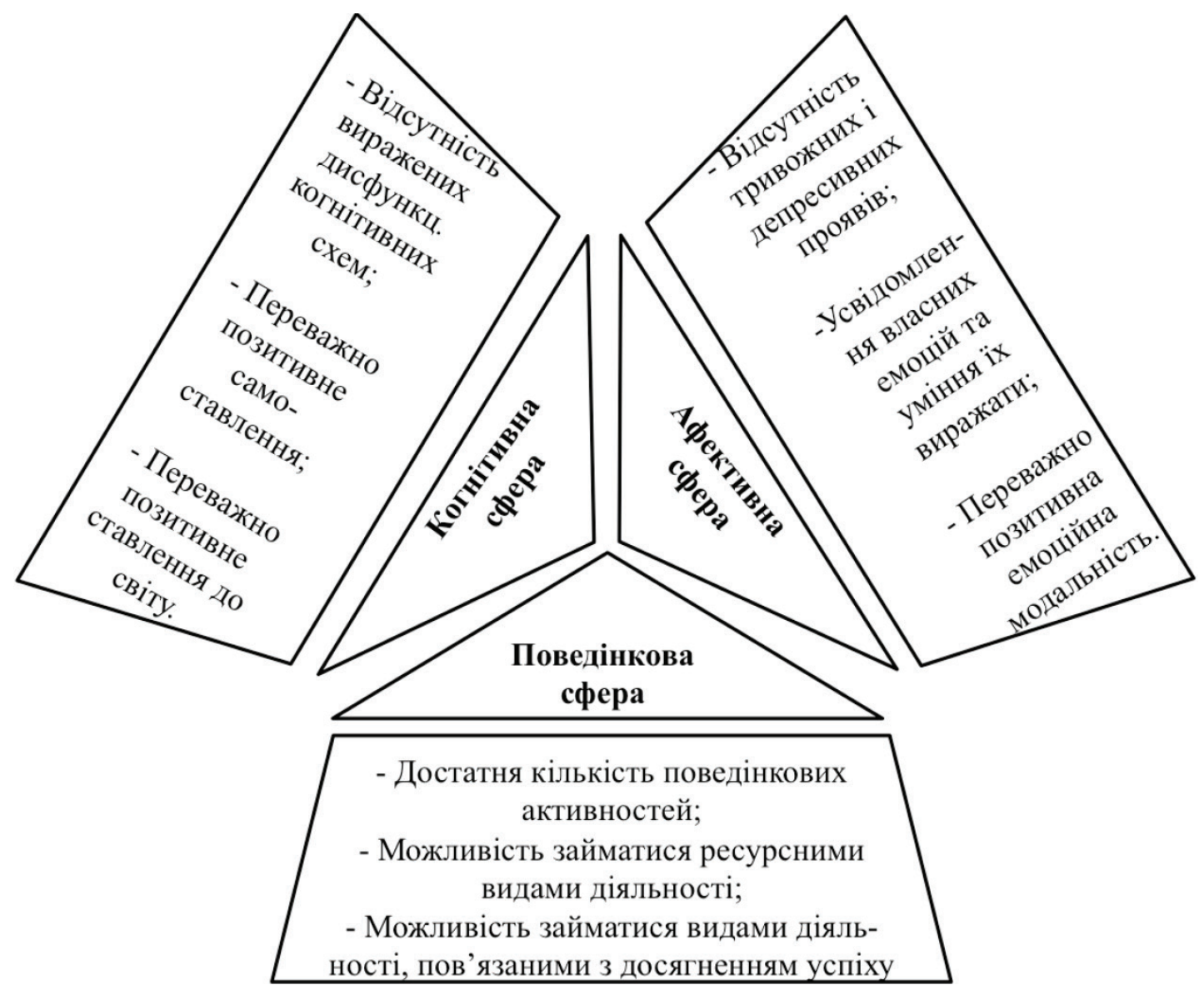

Рис. 1. Складники гармонійного особистісного становлення підлітків

Критерієм гармонійного становлення когнітивної сфери $є$ відсутність виражених дисфункційних схем, переважно позитивне самоставлення та переважно позитивне ставлення до світу. Науково доведено, що нормальною вважається повна відсутність притаманних людині дисфункційних схем, або ж прояв не більш, ніж 3 схем [2]. Якщо ж підліток демонструє високий рівень прояву 4 i більше з 18 схем, можна говорити про порушення гармонійності його особистісного становлення та загальну патологізацію цього процесу. Позитивне ставлення до себе $\epsilon$ результатом безумовної самооцінки та усвідомлення власної цінності [3]. Утім, ураховуючи нормативність достатньо різких коливань самооцінки в підлітковому віці, цей параметр варто вимірювати в контексті не абсолютних, а відносних величин. Саме тому тут використовується конструкт «переважно позитивне ставлення», який передбачає можливість прояву досить різноманітних аспектів самоставлення без порушення загального гармонійного перебігу особистісного становлення.

Відповідний підхід фіксується також і в контексті ставлення до світу. Таке ставлення формується, передусім, у контексті міжособистісної вза- ємодії. Оскільки одним з основних видів провідної діяльності на цьому етапі є спілкування з однолітками, саме успішність або неуспішність у цій сфері визначає низку параметрів світосприйняття, таких як: ставлення до інших людей, ставлення до навчання та академічна мотивація, оцінка власних можливостей та ін [4]. Тут, як і у випадку із самоставленням, достатнім $є$ переважання, а не абсолютна вираженість позитивного ставлення. Таким чином, реалізація трьох зазначених параметрів протягом всього процесу особистісної генези в підлітковому віці дозволяє говорити про гармонійність когнітивних проявів індивіда.

Гармонійне становлення афективної сфери особистості також реалізується за трьома параметрами. Першим параметром є відсутність тривожних і депресивних розладів. Такі розлади $\epsilon$ одними 3 найбільш розповсюджених серед порушень емоційної регуляції та за даними ВОО3 зустрічаються у більш, ніж $20 \%$ осіб [5]. При цьому вони суттєво знижують якість життя, негативно впливають не лише на психологічне благополуччя індивіда, але й на його фізіологічний стан, та здатні порушити процес становлення особистості підлітків, сповільнюючи його та спри- 
чиняючи формування патологічних особистісних рис [6]. Другий критерій, що входить до цієї сфери, передбачає усвідомленням власних емоцій та вміння конструктивно їх виражати, тобто передбачає достатній рівень розвитку емоційного інтелекту. Таке уміння сприяє зниженню психоемоційної напруги, що $є$ особливо значущим у період підлітковості, коли емоційна регуляція порушується внаслідок у тому числі й фізіологічних, гормональних змін [7]. Третім критерієм гармонійної підліткової емоційності $\epsilon$ переважання в індивіда позитивної емоційної модальності. Саме емоційна модальність забезпечує становлення притаманного особі загального емоційного фону, який $\epsilon$ передумовою для формування низки особистісних рис і проявів [8].

Складовими частинами гармонійного прояву поведінкової сфери в період підлітковості $є$ достатня кількість поведінкових активностей, можливість займатися ресурсними видами діяльності та можливість досягати успіху в певних видах діяльності. Поведінкові активності - це певні види діяльності індивіда, пов'язані з активацією, передусім, фізичної сфери. Заняття ними сприяє насиченню головного мозку киснем, синтезу низки гормонів, в тому числі й ендорфінів, що відповідають за підтримання позитивного психоемоційного стану [9]. Відповідно, депривація цих активностей не лише сповільнює фізичний розвиток організму, який $є$ принципово важливим на етапі підлітковості, але й сприяє пригніченню емоційної сфери та появі депресивних проявів, які, як було зазначено вище, $є$ передумовою формування патологічних рис особистості. Отже, гармонійне особистісне становлення обов'язково передбачає достатню кількість поведінкових активностей. Водночас ресурсні види діяльності можуть бути пов'язані не лише з фізичною (заняття спортом, туризм, активні прогулянки та ін.), але також і 3 інтелектуальною активацією (живопис, читання, вирішення складних інтелектуальних завдань та ін.). Такі види діяльності сприяють подоланню надмірної напруги та відновленню психоемоційного благополуччя, без якого гармонійне становлення особистості є неможливим [10]. Нарешті, можливість досягати успіху в певних видах діяльності, будучи однією 3 форм ресурсних активностей, дозволяє особі усвідомлювати власну цінність та впливає на становлення ставлення до себе та до навколишнього світу, що є ключовими компонентами когнітивної сфери.

Отже, очевидним $є$ те, що кожна із трьох особистісних сфер не лише включає параметри, без реалізації яких гармонійне становлення особистості $є$ неможливим, але й $є$ тісно пов'язаною із двома іншими. Це дозволяє припустити, що в разі депривації однієї із цих сфер у період особи- стісного становлення, можливою $є$ компенсація іiі функціонування за рахунок активації двох інших. Така ідея склала методологічну основу розроблених нами заходів, спрямованих на гармонізацію особистісного становлення підлітків.

Мета статті полягає у представленні авторської психопрофілактичної програми, спрямованої на гармонізацію особистісного становлення та аналіз результатів ефективності іiі реалізації 3 підлітками, які мають порушення слуху та зору, а також тими, хто не має таких порушень.

Виклад основного матеріалу дослідження. Визначення критеріїв гармонійного особистісного становлення підлітків дозволило розробити модель цілеспрямованого психологічного впливу, мета якого полягає в полегшенні перебігу кризового етапу особистісного становлення в підлітковому віці та формуванні суб'єктивного відчуття задоволеності підлітків власним життям. Досягнення зазначеної мети стало можливим за рахунок реалізації таких завдань: 1) виокремити аспекти психічного життя підлітків, цілеспрямований вплив на які дозволить гармонізувати процес їх особистісного становлення; 2) визначити загальну методологію та підібрати окремі методи i техніки цілеспрямованого психологічного впливу; 3) на основі розробленої методології створити програму психопрофілактичної роботи 3 підлітками; 4) емпірично перевірити ефективність такої роботи 3 підлітками, чиє особистісне становлення відбувається в межах онто- та дизонтогенезу.

Психологічна профілактика відбувалась у форматі тренінгу особистісного зростання, принциповою характеристикою якого стала його орієнтація на ключові сфери особистісного становлення, а також можливість реалізації в роботі з підлітками, які мають порушення слуху і зору.

Зважаючи на призначення тренінгу для психічно здорових учасників, чиє особистісне становлення $€$ загалом гармонійним, логіка подачі матеріалу передбачала достатньо високу інтенсивність та значну кількість завдань для самостійного опрацювання. Тривалість реалізації програми склала 4 тижні. На першому етапі тренінгової роботи, окрім знайомства, відбувалась також соціалізація учасників в активність такого формату та психоедукація щодо гармонійного функціонування особистості загалом та проблем особистісного становлення в підлітковому віці зокрема. Визначною характеристикою цього етапу роботи стало включення до нього блоку самопізнання та рефлексії, який передбачав знайомство учасників 3 низкою особистісних конструктів (таких, як самооцінка, особистісні та характерологічні риси, ціннісні орієнтири та ін.) та самоаналіз щодо рівня та особливостей прояву в них зазначених конструктів. 
При цьому, крім іншого, відбувалось ознайомлення учасників із показниками, отриманими в ході їх попередньої психологічної діагностики, та порівняння результатів самоаналізу 3 даними інструментальних досліджень. Такий підхід дозволив, 3 одного боку, поглибити саморозуміння підлітків, а з іншого - допомогти їм знайти сфери максимально ефективної реалізації власних унікальних особистісних проявів. Складанню списку таких сфер було присвячене перше тренінгове домашнє завдання.

Другий етап роботи інтегрував афективний та когнітивний блоки. Тобто частина тренінгових активностей була присвячена розвитку емоційного інтелекту, а інша частина - аналізу проблеми особистісних когніцій, усвідомленню учасниками тих когніцій, які $є$ типовими для них, а також знайомству 3 поняттям корисних ментальних активностей та віднайденню ресурсних для себе активностей. Як домашнє завдання підліткам пропонувалось впроваджувати в повсякденне життя отримані знання і уміння (практикувати ресурсні ментальні активності та відпрацьовувати навички розуміння і вираження емоцій) і фіксувати свої труднощі та досягнення у спеціальних формах для самозвітів.

У межах третього психопрофілактичного етапу відбувалося стратегічне планування поведінкових активностей. Основна увага при цьому приділялась орієнтації сформульованих планів на цілі та цінності особистості. Аналіз особистісних цінностей учасників відбувається 3 використанням низки якісних методів, таких як рефлексія та самоаналіз, групове обговорення та конструювання життєвих ситуацій. При цьому програма тренінгу не передбачала діагностики ціннісної сфери 3 використанням стандартизованих психодіагностичних методик. Таке рішення було прийняте 3 огляду на те, що широта та різноаспектність змістового наповнення ціннісної сфери особистості визначає необхідність її вивчення та аналізу, спираючись виключно на методи та техніки якісного характеру. Відповідний підхід дозволив продемонструвати підліткам варіативність у прояві цінностей, а також можливість їх трансформації протягом різних етапів життя. Водночас опанування рефлексивних технік для аналізу ціннісної сфери забезпечує учасників тренінгу ефективними інструментами для подальшої самодіагностики ціннісної сфери та відповідної корекції поведінкових стратегій.

На основі визначених цінностей відбувалося формулювання оперативних та стратегічних цілей. При цьому використовувались традиційні для такої роботи техніки визначення пріоритетів та оцінки ризиків. Крім того, кожна ціль проходила верифікацію та тестування на відповідність низці критеріїв. Далі в межах поточного етапу роботи відбувалось оперативне та стратегічне планування, тобто розроблялись покрокові поведінкові алгоритми, спрямовані на досягнення окремих конкретних цілей та орієнтовний план діяльності на найближчі п'ять років, дотримання якого дозволить досягнути більш складних та довгострокових цілей. Таким чином, робота, що розпочалась у межах тренінгу, не завершувалась 3 його закінченням, а інтегрувалась у повсякденне життя учасників.

Останній етап реалізації психопрофілактичної програми передбачав не лише традиційне для роботи такого формату узагальнення та підведення підсумків, а й додатковий блок роботи, присвячений самоаналізу та рефлексії. У межах цього блоку підлітки поверталися до аналізу власних особистісних рис і проявів, який було розпочато на першому етапі тренінгової роботи, проте робили це 3 інших позицій, зважаючи на новий досвід, знання та навички, отримані в процесі участі у тренінгу. На основі самоаналізу та обговорення у групі вибудовувались особистісні профілі усіх учасників, які включали їхні ключові характеристики, сильні сторони та ресурси, а також ті сфери практичної діяльності, в яких вони можуть реалізуватись максимально комфортно і успішно.

Психопрофілактична програма також передбачала можливість реалізації як очно, у груповому форматі, так і у форматі онлайн. Це дозволило продовжувати працювати над апробацією програми, попри об'єктивні обмеження, пов'язані із загальнонаціональним карантином. У межах онлайн-формату психопрофілактичної програми представлено диверсифікований підхід в оцінці виконаних учасниками домашніх завдань. Тобто частина формальних завдань та результатів діагностичних вимірювань оцінювалась автоматично, і на основі такої оцінки приймалось рішення про перехід учасників до опанування наступних етапів або про повторне проходження матеріалу. Водночас частина завдань 3 огляду на їх складність та багатоаспектність (рефлексивні щоденники та есе) передбачала особисту оцінку психологом-тренером та надання учасникам зворотного зв'язку.

У ході апробації психопрофілактичної програми iї було реалізовано з 6 групами у форматі безпосередньої взаємодії та 351 учасником у форматі онлайн (що за обсягом відповідає 4 робочим групам). При цьому підлітків, які взяли участь у тренінгу, можна умовно розподілити на 3 групи: група $\mathrm{A}$ - ті, які мають порушення слуху, група Б - ті, які мають порушення зору і група В - ті, які не мають порушень у роботі аналізаторів. 3 огляду на низку причин онлайн-робота проводилась виключно з останньою категорією учасників. 
Водночас серед 6 тренінгів, проведених у форматі безпосередньої взаємодії, три включали учасників із групи В, по одному - учасників із груп А і Б, та ще один тренінг інтегрував учасників 3 груп А $\mathrm{i}$ $\mathrm{B}$, що дало змогу перевірити гіпотезу про ефективність психопрофілактичної роботи в контексті інклюзивного навчально-виховного процесу.

Реалізація та апробація програми психологічної профілактики відбувалась протягом 2016-2020 років. Загальна кількість учасників, залучених до тренінгової роботи, склала 135 осіб. Вік учасників коливався в діапазоні від 14 до 17 років.

Як критерії ефективності реалізації програми використовувались показники суб'єктивних шкал задоволеності життям. Показники до таких шкал вносились підлітками на початку кожного заняття та обговорювались у групі. Це дозволило проводити постійний моніторинг динаміки змін, що відбувались у психоемоційному стані учасників, та, в разі необхідності, вносити у програму допустимі корективи. Крім того, на основі порівняння показників суб'єктивної задоволеності життям, які демонстрували учасники на початку тренінгу 3 аналогічними даними, отриманими після його завершення, відбувався аналіз ефективності тренінгових програм та визначення доцільності їх застосування в межах психопрофілактичної та психокорекційної роботи.

Статистичний аналіз даних відбувався з використанням t-критерію Стьюдента для залежних вибірок. Вибір такого методу був зумовлений його придатністю для перевірки гіпотези про те, що середні значення двох генеральних сукупностей, з яких вилучені порівнювані залежні вибірки, відрізняються одна від одної. При цьому припускається можливість порівняння результатів, отриманих на одній вибірці в різних темпоральних точках (напр., до певного впливу та після нього).

$\mathrm{У}$ таблиці 1 представлено показники $\mathrm{t}$-критерію Стьюдента, а також середні величини та стандартні відхилення для кожної із п'яти груп рес- пондентів: А (тих, що мають порушення слуху), Б (тих, що мають порушення зору), В (тих, що мають порушень у роботі аналізаторів) - окремо для груп, які працювали офлайн (у форматі очних зустрічей) та онлайн (в дистанційному форматі) та А+В, в якій було об'єднано для роботи підлітків із двох відповідних груп.

Узагальнюючи показники ефективності реалізації програми психологічної профілактики, можемо зауважити, що позитивна динаміка була характерною для кожної 3 респондентських груп. Проте змістові характеристики такої динаміки відрізняються залежно від індивідуальних особливостей респондентів, тож доцільним $є$ їх детальний аналіз.

Найбільш ефективною $(\mathrm{t}=7,809)$ програма виявилась для підлітків із групи $\mathrm{B}$, робота 3 якими відбувалась в очному форматі. Це дозволяє зробити висновок про загальну резильєнтність підлітків, чиє особистісне становлення відбувається в контексті онтогенезу, та про їх більш високу готовність до позитивних змін внаслідок цілеспрямованого психологічного впливу. Водночас показники ефективності дистанційної роботи 3 аналогічною категорією учасників виявились не такими високими $(\mathrm{t}=2,492)$ та хоча і свідчать про наявність позитивних тенденцій, демонструють також їх деяку слабкість. Причину таких результатів ми вбачаємо в нетрадиційності цього формату роботи, окремих технічних труднощах, неможливості використовувати групову динаміку, яка сама по собі $є$ ефективним засобом впливу, а також недостатній самодисциплінованості підлітків, що мала безпосередній вплив на їх відповідальність у виконанні тренінгових завдань.

Схожі показники ефективності були зафіксовані у групах $\mathrm{A}(\mathrm{t}=3,712)$ та $\mathrm{A}+\mathrm{B}(\mathrm{t}=3,093)$. Такі дані, будучи достатньо значимими, свідчать про однакову ефективність роботи як з однорідними тренінговими групами, що включають підлітків із порушеннями слуху, так і з інтегрованими групами, до яких одночасно входять особи з відповід-

\section{Статистичні значення показників ефективності реалізації психопрофілактичної та психокорекційної програм}

\begin{tabular}{|l|c|c|c|c|c|}
\hline \multirow{2}{*}{$\begin{array}{c}\text { Група } \\
\text { респондентів }\end{array}$} & \multicolumn{2}{c|}{ До тренінгу } & \multicolumn{2}{c|}{ Після тренінгу } & \multirow{2}{*}{ t * } \\
\cline { 2 - 5 } & $\mathrm{M}$ & $\mathrm{SD}$ & $\mathrm{M}$ & $\mathrm{SD}$ & \\
\hline \multicolumn{5}{|c|}{ Психологічна профілактика } \\
\hline Група А & 64,2143 & 15,6656 & 76,2857 & 11,0553 & 3,712 \\
\hline Група Б & 74,2727 & 9,2530 & 80,0000 & 7,4297 & 2,773 \\
\hline Група В (офлайн) & 64,8182 & 14,8595 & 81,4091 & 8,6005 & 7,809 \\
\hline Група В (онлайн) & 74,3273 & 14,4120 & 79,9091 & 9,5030 & 2,392 \\
\hline Група А+В & 72,4667 & 11,9933 & 79,1333 & 11,1218 & 3,093 \\
\hline
\end{tabular}

* усі показники t-критерія є значимими на рівні $>0,05$ 
ними порушеннями та їх однолітки, які не мають таких порушень. Це можна вважати непрямим підтвердженням нашої гіпотези про нормативність особистісного становлення підлітків, що відбувається в контексті дизонтогенезу, та про його відповідність загальним віковим стандартам і, як наслідок, - про можливість та доцільність психопрофілактичної роботи в інклюзивному форматі.

Значимість показників t-критерію для вибірки підлітків, які мають порушення зору $(\mathrm{t}=2,773)$, дозволяє зробити загальний висновок про універсальність програми психологічної профілактики та доцільність i застосування для підтримання гармонійності особистісного становлення підлітків в онтогенезі та дизонтогенезі.

Із-поміж отриманих на цьому етапі дослідження показників вартими уваги $є$ також відомості щодо середніх величин за шкалами суб'єктивної задоволеності життям для різних категорій досліджуваних. До початку тренінгу найнижчі показники за зазначеною шкалою продемонстрували підлітки 3 групи А $(\mathrm{M=64,2143).} \mathrm{Водночас}$ показники представників групи В, залучених до роботи у форматі очних зустрічей були наближеними до цього рівня (M=64,8182). Проте у фінальних показниках цих двох груп досліджуваних спостерігались суттєві відмінності. У результаті участі у тренінгу рівень суб'єктивного благополуччя підлітків, які мають порушення слуху, підвищився на 12 пунктів 3100 (M=76,2857), тоді як показники показники їх однолітків без відповідних порушень підвищились на одразу на 17 пунктів (M=81,4091). Тобто швидкість прояву та інтенсивність позитивної динаміки змін корелює 3 функціональними особливостями респондентів.

Висновки. Результати статистичного аналізу даних, отриманих у ході практичної апробації та впровадження програми психологічної профілактики, спрямованої на підтримання гармонійності особистісного становлення, свідчать про ii загальну ефективність та доцільність застосування в роботі з різними категоріями підлітків.

Специфіка програми полягає в ії спрямованості на роботу із трьома основними сферами особистості: когнітивною, афективною та поведінковою, а також в її методологічній орієнтації на загальні принципи та окремі методики когнітивно-поведінкової терапії. Такий підхід дозволив комплексно оцінити особистісні прояви учасників та науково-обгрунтовано підійти до практичної роботи з ними.

У процесі апробації програми було охоплено три групи підлітків: тих, які мають порушення слуху або зору, а також тих, які не мають порушень у роботі аналізаторів. Тренінгова робота проводилась як із представниками кожної групи окремо, так і в інклюзивному форматі для змішаних груп. Крім того, розроблена програма передбачає можливість реалізації в дистанційному форматі, що $\epsilon$ актуальним в умовах карантинних обмежень. Дані, отримані в результаті апробації програми в різних форматах та на різних вибірках, підтверджують їі ефективність.

Таким чином, описана програма психологічної профілактики може бути використана для практичної роботи з підлітками, чиє особистісне становлення відбувається як у контексті онтогенезу, так і в контексті дизонтогенезу. Перспективи подальшої діяльності в цьому напрямі ми вбачаємо у вдосконаленні дистанційної модифікації програми та в розробці специфічних алгоритмів їі реалізації на базі наявних інтернет-майданчиків, призначених для такої роботи.

\section{ЛІТЕРАТУРА}

1. Литвиненко О.О. Взаємозв'язок когніцій та емоцій підлітків у контексті їх особистісного становлення. Психологічний часопис. 2020. Том 6. № 4. С. 159-168. URL : https://doi.org/10.31108/1.2020.6.4.

2. Арнц А. Схема-терапія: модель роботи з частками. Львів : Свічадо, 2014. 264 с.

3. Caspi A., Roberts B., Shiner R (2005) Personality Development: Stability and Change. - Annual Reviews of Psychology. P. 453-571.

4. Круглова Т.Е. Особенности эмоциональной сферы подростков с разной успеваемостью. Молодой ученьий. 2017. № 9(143). С. 281-284.

5. Лукьянова И.И. Базовые потребности возраста как основа развития социальной компетентности у подростков. Психологическая наука и образование. 2011. № 4. С. 41-47.

6. World Health Organization (2016). Intervention Guide for mental, neurological and substance use disorders in non-specialized health settings. ISBN: 9789241549790.

7. Beck, A. (2014). Depression: Causes and Treatment, Second Edition. Pennsylvania: University of Pennsylvania Press.

8. Greenberg, L. \& Paivio, S. (2007). Working with Emotions in Psychiatry. New York : The Guilford Press.

9. Изард К. Психология эмоций. Санкт-Петербург : Питер, 2012. 464 с. ISBN: 5314000679.

10. Martell, C., Dimidjian, S. \& Herman-Dunn, R. (2010). Behavioral activation for depression: a clinician's guide. The Guilford Press. New Yourk. 


\section{REFERENCES}

1. Lytvynenko O. O. Vzayemozv'yazok kohnitsiy ta emotsiy pidlitkiv u konteksti yikh osobystisnoho stanovlennya [The corelation between adolescents' cognitions and emotions in the context of their personal formation]. Psykholohichnyy chasopys [Psychological Journal]. 2020. Volume 6. №4. P. 159-168. https://doi.org/10.31108/1.2020.6.4 [in Ukrainian].

2. Arntz A. (2014) Skhema-terapiya: model roboty z chastkamy [Scheme-therapy: a model of work with particles]. Lviv : Svichado. 264 p. [in Ukrainian].

3. Caspi, A., Roberts, B., Shiner, R (2005) Personality Development: Stability and Change. - Annual Reviews of Psychology. - P. 453-571.

4. Kruglova T. E. Osobennosti emotsional'noy sfery podrostkov s raznoy uspevayemost'yu [Features of the emotional sphere of adolescents with different academic performance]. Molodoy uchenyy [Young scientist]. 2017. No. 9 (143). P. 281-284. [in Russian].

5. Lukyanova I. I. Bazovyye potrebnosti vozrasta kak osnova razvitiya sotsial'noy kompetentnosti u podrostkov. [Basic needs of age as the basis for the development of adolescents' social competence]. Psikhologicheskaya nauka i obrazovaniye. [Psychological science and education]. 2011. No. 4. P. 41-47. [in Russian].

6. World Health Organization (2016). Intervention Guide for mental, neurological and substance use disorders in non-specialized health settings. ISBN: 9789241549790

7. Beck, A. (2014). Depression: Causes and Treatment, Second Edition. Pennsylvania: University of Pennsylvania Press.

8. Greenberg, L. \& Paivio, S. (2007). Working with Emotions in Psychiatry. New York: The Guilford Press.

9. Izard K. [Psikhologiya emotsiy] Psychology of emotions. St. Petersburg: Peter. 2012. 464 p. ISBN: 5314000679. [in Russian].

10. Martell, C., Dimidjian, S. \& Herman-Dunn, R. (2010). Behavioral activation for depression: a clinician's guide. The Guilford Press. New Yourk. 